\title{
Infliximab in ankylosing spondylitis: alone or in combination with methotrexate? A pharmacokinetic comparative study
}

\author{
Denis Mulleman ${ }^{1,2^{*}}$, Francine Lauféron ${ }^{1,2}$, Daniel Wendling ${ }^{3,4}$, David Ternant $^{1,5}$, Emilie Ducourau $^{1,2}$, \\ Gilles Paintaud $^{1,5}$ and Philippe Goupille $e^{1,2,6}$
}

\begin{abstract}
Introduction: Methotrexate (MTX) has been shown to modify infliximab pharmacokinetics in rheumatoid arthritis. However, its combination with infliximab in the treatment of ankylosing spondylitis (AS) is not recommended. The objective of this study was to examine the influence of MTX on infliximab exposure in patients with AS.

Methods: Patients with AS patients who had predominantly axial symptoms were randomised to receive infliximab alone (infusions of $5 \mathrm{mg} / \mathrm{kg}$ at weeks $0,2,6,12$ and 18) or infliximab combined with MTX (10 mg/week). Infliximab concentrations were measured before and 2 hours after each infusion and at 1, 3, 4, 5, 8, 10, 14 and 18 weeks. We estimated individual cumulative area under the concentration versus time curves (AUC) for infliximab concentration between baseline and week $18\left(\mathrm{AUC}_{0-18}\right)$. Clinical and laboratory evaluations were performed at each visit. The Bath Ankylosing Spondylitis Disease Activity Index (BASDAI) score was the primary end point for clinical response.

Results: Twenty-six patients were included (infliximab group: $n=12$, infliximab + MTX group: $n=14$ ), and 507 serum samples were available for measurement of infliximab concentration. The two groups did not differ with regard to $\mathrm{AUC}_{0-18}$ or evolution of BASDAI scores and biomarkers of inflammation.
\end{abstract}

Conclusions: The combination of MTX and infliximab does not increase the exposure to infliximab over infliximab alone in patients with AS.

Trial registration: ClinicalTrials.gov: NCT00507403

\section{Introduction}

Infliximab, a chimeric monoclonal antibody to TNF- $\alpha$, showed efficacy for ankylosing spondylitis (AS) in a randomised, placebo-controlled trial in which $61.2 \%$ of the patients were responders at 24 weeks [1]. Although methotrexate (MTX) is often used for patients with predominantly peripheral AS and those with psoriatic arthritis, the few attempts to treat predominantly axial disease were disappointing. Haibel et al. [2] studied 20 patients with AS who received MTX 15 to $20 \mathrm{mg} /$ week subcutaneously and found no difference in Assessment in Ankylosing Spondylitis 20\% improvement criteria

\footnotetext{
* Correspondence: mulleman@med.univ-tours.fr

${ }^{1}$ Université François-Rabelais de Tours, Centre National de la Recherche Scientifique UMR 6239 GICC (Génétique Immunothérapie Chimie et Cancer), 3 rue des Tanneurs, F-37041 Tours Cedex 1, France

Full list of author information is available at the end of the article
}

(ASAS 20) scores before and 16 weeks after treatment. Until now, MTX has been evaluated in only three small, randomised, controlled trials [3-5], and a Cochrane review [6] concluded that there was insufficient evidence to support the use of MTX for AS with predominantly axial symptoms.

Data comparing infliximab with and without MTX treatment in AS are sparse and conflicting. Pérez-Guijo et al. [7] found a greater reduction in Bath Ankylosing Spondylitis Disease Activity Index (BASDAI) scores with infliximab + MTX treatment than with infliximab alone, whereas Breban et al. [8] found no statistically significant difference between patients who did or did not receive MTX in a subset of AS patients receiving treatment with infliximab by an on-demand strategy. However, in the latter study, patients receiving MTX showed a better response and fewer reactions to infusions than

\section{C) Biomed Central}


did patients not receiving MTX, although the results were not statistically significant [8]. Currently, regarding TNF- $\alpha$ antagonist therapy for patients with AS or psoriatic arthritis, the French Society for Rheumatology recommendations suggest that there is insufficient evidence for concomitant disease-modifying antirheumatic drugs improving the effectiveness of TNF- $\alpha$ antagonist therapy [9].

To date, no study has used infliximab exposure as an end point to compare treatment with the combination of infliximab and MTX with infliximab alone in AS with predominantly axial symptoms. Indeed, if such a combination increases exposure to infliximab, it should improve response and may be recommended in clinical practice. In the present study, we compared the individual exposure to infliximab of AS patients with predominantly axial symptoms receiving infliximab alone or infliximab and MTX combined.

\section{Materials and methods}

\section{Patients and study protocol}

From January 2008 to April 2009, AS patients with predominantly axial symptoms were recruited to participate in this two-centre, open-label, prospective, randomised study comparing treatment with infliximab alone and infliximab with MTX. All patients fulfilled the New York revised criteria for AS [10]. Infliximab was given intravenously $(5 \mathrm{mg} / \mathrm{kg})$ at weeks $0,2,6,12$ and 18 in accordance with our guidelines [9]. MTX $10 \mathrm{mg}$ was given orally every week. After patients were randomised to a treatment group, a total of 12 visits were scheduled at each infliximab infusion and between infusions at 1, 3, 4, $5,8,10$ and 14 weeks. Blood samples were collected before and two hours after the end of each infusion and at each visit. We estimated that we needed about 30 patients to compare infliximab exposure between the two treatment groups. The study protocol was in compliance with the Declaration of Helsinki, approved by the ethic committee of Tours University Hospital and registered (ClinicalTrials.gov ID: NCT00507403). All patients gave their informed consent to participate in the study.

\section{Clinical measurements}

At each visit, patients were asked to complete a BASDAI questionnaire and were classified as responders if their BASDAI score (on a 10-point scale) at week 18 was two points lower than at baseline $[9,11]$. Treatment response was also assessed according to the Assessment in Ankylosing Spondylitis 20\% improvement criteria (ASAS 20).

\section{Serum infliximab and antibodies toward infliximab concentrations}

Analyses of serum infliximab and antibody toward infliximab (ATI) concentrations were centralised in
Tours University Hospital. Infliximab serum concentration was measured in samples by using ELISA as described previously [12]. Serum concentration of ATI was measured by using a double-antigen ELISA on the basis of capture by infliximab-coated microplates and detection by peroxidase-conjugated infliximab. This assay was standardised by the use of a mouse monoclonal antibody against human immunoglobulin G. The positive threshold of detection was $0.07 \mathrm{mg} / \mathrm{L}$. Because of the interference of circulating infliximab, only sera with infliximab concentrations $<2 \mathrm{mg} / \mathrm{L}$ were tested.

\section{Statistical analysis}

Individual exposure to infliximab was estimated by the cumulative area under the concentration versus time curve between baseline and week $18\left(\mathrm{AUC}_{0-18}\right)$ by population pharmacokinetics modelling. The best description of infliximab concentrations was obtained by use of a two-compartment model with first-order distribution and elimination constants. Characteristics at baseline and the proportion of responders in each group were compared by using nonparametric tests. The results are presented in Table 1 as medians [range] unless otherwise stated. Statistical analysis involved the use of $\mathrm{R}$ 2.7.2 software [13].

\section{Results}

We included 26 patients: 12 in the infliximab-only group and 14 in the infliximab + MTX group. The patients' characteristics at baseline are given in Table 1. A total of 507 samples were available for measurement of serum infliximab concentrations. Individual $\mathrm{AUC}_{0-18}$ results for

\begin{tabular}{|c|c|c|c|}
\hline Characteristics & $\begin{array}{l}\text { Infliximab } \\
(n=12)\end{array}$ & $\begin{array}{c}\text { Infliximab + } \\
\text { MTX } \\
(n=14)\end{array}$ & $\begin{array}{c}P \\
\text { value }\end{array}$ \\
\hline Sex, men/women (n/\%) & $9 / 3(75 / 25)$ & $11 / 3(79 / 21)$ & 0.8 \\
\hline Median age, years & $\begin{array}{c}42.5[27 \text { to } \\
59]\end{array}$ & 45.5 [29 to 55$]$ & 0.3 \\
\hline Median disease duration, years & $4.0[0$ to 28$]$ & 4.5 [1 to 19$]$ & 0.9 \\
\hline $\begin{array}{l}\text { Human leukocyte antigen } B 27^{+} \text {, } \\
n(\%)\end{array}$ & $9(75)$ & $10(71)$ & 0.8 \\
\hline NSAIDs, $n(\%)$ & $8(67)$ & $12(86)$ & 0.5 \\
\hline Previous TNF- $\alpha, n$ (\%) & $2(17)$ & $2(14)$ & 1.0 \\
\hline Median BASDAI score & $\begin{array}{l}5.8[3.9 \text { to } \\
8.4]\end{array}$ & $7.0[5.0$ to 8.2$]$ & 0.2 \\
\hline Median C-reactive protein, mg/L & $\begin{array}{c}3.6[0.5 \text { to } \\
18.0]\end{array}$ & $\begin{array}{c}2.7[0.5 \text { to } \\
31.2]\end{array}$ & 0.5 \\
\hline
\end{tabular}

${ }^{a}$ MTX: methotrexate; BASDAl: Bath Ankylosing Spondylitis Disease Activity Index; NSAIDs: nonsteroidal anti-inflammatory drugs. Results are given as medians [range] unless otherwise indicated. 


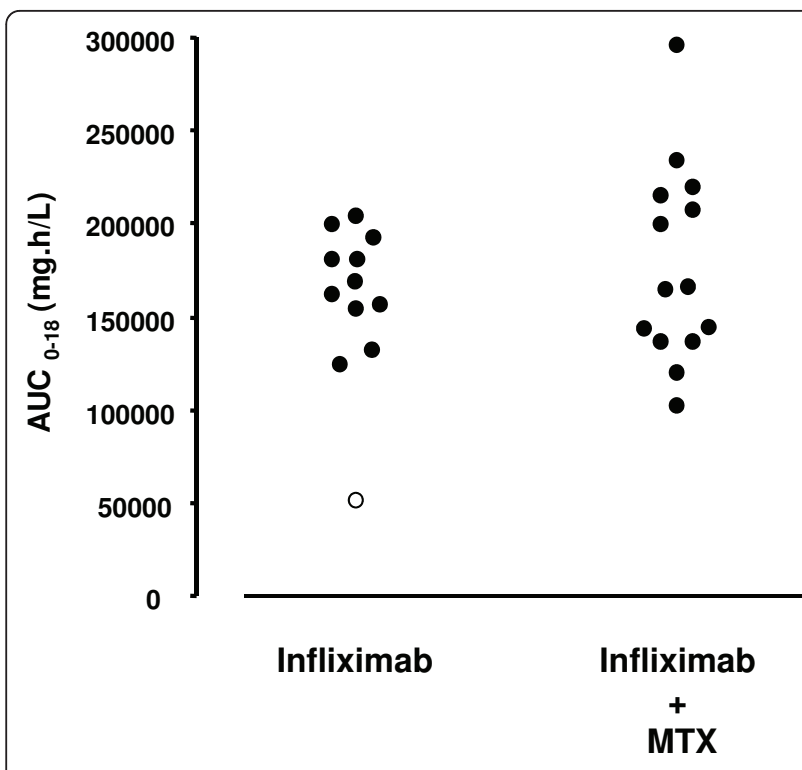

Figure 1 Area under the concentration curve versus the time curve for serum infliximab concentration between baseline and week $18\left(\mathrm{AUC}_{0-18}\right)$ for patients with ankylosing spondylitis who had predominantly axial symptoms and were receiving infliximab or infliximab + methotrexate (MTX) treatment. The patient with anti-infliximab antibodies is shown as an open circle.

infliximab are shown in Figure 1. The two treatment groups did not differ in terms of $\mathrm{AUC}_{0-18}$ results. The median $\mathrm{AUC}_{0-18}$ value was $165,502 \mathrm{mg} /$ hour/L [50,569 to 203,782 ] for the infliximab-only group and 164,222 mg/ hour/L [102,165 to 295,858] for the infliximab + MTX group. Likewise, MTX had no effect on estimated pharmacokinetics parameters (data not shown). Positivity for ATI was detected in only one patient, a 43-year-old woman in the infliximab-only group who was negative for human leukocyte antigen B27. At weeks 4, 5 and 6, her infliximab concentrations were $<1 \mathrm{mg} / \mathrm{L}$ and ATIs were detected at weeks 12 and 18. Her exposure to infliximab was low $\left(\mathrm{AUC}_{0-18}=50,569 \mathrm{mg} / \mathrm{hour} / \mathrm{L}\right)$, and the infliximab elimination clearance was twice that of ATI-negative patients (data not shown).

The two groups did not differ with regard to clinical activity or inflammation. Responses between the two groups were similar at week 18 (Additional file 1). Responders displayed a rapid decrease in BASDAI score compared with nonresponders, with a statistically significant difference observed at week 6 and thereafter (Additional file 2). The proportions of previous antiTNF- $\alpha$ and current NSAIDs were similar in both responders and nonresponders.

\section{Discussion}

We did not observe any influence of MTX on infliximab exposure in AS patients with predominantly axial symptoms. Our study is the first to answer the question whether MTX may affect infliximab pharmacokinetics in AS with predominantly axial symptoms. Previously, Krisiek et al. [14] analysed blood samples from AS patients receiving treatment with infliximab by an on-demand strategy with or without MTX. In their post hoc analysis involving 34 patients receiving MTX and 42 patients not receiving MTX, infliximab concentrations were measured at weeks 2 and 6 after treatment. The authors found no significant difference in infliximab levels between the two groups. Our results are in agreement with these previously published results and provide a precise estimation of the drug exposure with repeated and prolonged measurement of infliximab.

We found no difference between treatment groups with regard to change in BASDAI scores or ASAS 20 criteria, findings which are in agreement with results from previous controlled trials [3-5]. Although clinical outcome was not our objective, our results do not argue for a clinical benefit of adding MTX to infliximab treatment $(5 \mathrm{mg} / \mathrm{kg} /$ infusion) for AS with predominantly axial symptoms. Patients who were responders at week 18 showed a rapid decrease in BASDAI scores, which suggests that an early decrease in BASDAI score may predict a response later on. By contrast, a patient who has not responded at 6 weeks after initiation seems likely to be a primary nonresponder.

The MTX dosage we used, $10 \mathrm{mg} /$ week orally, was in agreement with the recommendation by an expert opinion of a broad international panel of rheumatologists [15]. A subcutaneous route or higher dosage than 10 mg/week would not likely have changed our results, because a previous study found no clinical response in patients with AS receiving MTX 15 to $20 \mathrm{mg} /$ week subcutaneously [2].

We observed an important variability in infliximab exposure in both groups of patients. This variability has been reported in previous studies in which trough concentration was measured $[14,16]$. Our study provides a more precise characterisation of this variability and confirms that exposure to treatment differs considerably among individuals.

We found that one patient was positive for ATI. Of note, this patient did not receive MTX, and this finding raises the question of the hypothetical role of immunosuppressive agents in preventing immunisation as reported in rheumatoid arthritis (RA) and Crohn's disease [17-19]. Because of the small number of participants and the relatively short duration of the study, no conclusion can be drawn regarding the potential role of MTX in reducing immunogenicity in AS.

Our results differ from those of Maini et al. [17], who found that MTX increased infliximab concentrations in RA. In RA, disease activity at baseline was found to be 
negatively associated with infliximab trough concentration at 6 weeks after initiation of treatment [20,21]. This phenomenon may be explained by targeted mediateddrug disposition and high levels of TNF- $\alpha$ (which corresponds to antigenic burden) binding infliximab, which influence its pharmacokinetics. MTX is effective as monotherapy in patients with RA by decreasing TNF- $\alpha$ levels, which in turn increase infliximab concentrations [17]. That MTX did not improve infliximab exposure in our study patients with AS who had predominantly axial symptoms may reflect the fact that TNF- $\alpha$ antigenic burden is lower in AS than in RA.

\section{Conclusion}

MTX seems to have no significant effect on infliximab pharmacokinetics in AS with predominantly axial symptoms. These results do not argue for adding MTX to infliximab therapy in this condition.

\section{Additional material}

Additional file 1: Figure S1. Percentage of responders according to Bath Ankylosing Spondylitis Disease Activity Index (BASDAI) score ( > 2point reduction between baseline and week 18) and Assessment in Ankylosing Spondylitis 20\% improvement criteria (ASAS 20) for patients with ankylosing spondylitis who had predominantly axial symptoms and were receiving infliximab or infliximab + methotrexate (MTX) treatment.

Additional file 2: Figure S2. Changes in BASDAI scores for treatment responders (filled circles; $n=12$ ) and nonresponders (open circles; $n=$ 14) receiving infliximab alone or infliximab + methotrexate treatment. ${ }^{\dagger} P$ $<0.05 .{ }^{\ddagger} p<0.01$

\section{Abbreviations}

AS: ankylosing spondylitis; ASAS 20: Assessment in Ankylosing Spondylitis 20\% improvement criteria; ATI: antibody toward infliximab; AUC: area under the concentration versus time curve; BASDAl: Bath Ankylosing Spondylitis Disease Activity Index; ELISA: enzyme-linked immunosorbent assay; MTX: methotrexate; NSAID: nonsteroidal anti-inflammatory drug; RA: rheumatoid arthritis; TNF-a: tumour necrosis factor a.

\section{Acknowledgements}

The authors thank Nelly Jaccaz-Vallée, Sergine Gosset, Hélène Bansard, Fanny Teasdale and Elisabeth Jeannet for blood sampling; Anne-Claire Duveau for technical assistance in infliximab concentration and antibody toward infliximab measurements; Wiebe De Jong for technical support with the study protocol and data management; and Laura Heraty for her kind assistance with the manuscript. The University Hospital of Tours, France, received funding from the French Ministry of Health and Sport for this clinical trial within the framework of the 'Programme Hospitalier de Recherche Clinique 2004'.

\section{Author details}

'Université François-Rabelais de Tours, Centre National de la Recherche Scientifique UMR 6239 GICC (Génétique Immunothérapie Chimie et Cancer), 3 rue des Tanneurs, F-37041 Tours Cedex 1, France. ${ }^{2}$ Service de Rhumatologie, Centre Hospitalier Régional et Universitaire de Tours, avenue de la République, F-37044 Tours Cedex 9, France. '3niversité de FrancheComté, EA 4266 API (Agents Pathogènes et Inflammation), Hôpital Saint Jacques, 2 place Saint-Jacques, F-25030 Besançon Cedex, Besançon, France. ${ }^{4}$ Service de Rhumatologie, Centre Hospitalier Régional et Universitaire de Besançon, Hôpital Jean Minjoz, 3 boulevard Alexander Fleming, F-25030
Besançon Cedex, Besançon, France. ${ }^{5}$ Laboratoire de PharmacologieToxicologie, Centre Hospitalier Régional et Universitaire de Tours, 2 boulevard Tonnellé, F-37044 Tours Cedex 9, France. ${ }^{6}$ Institut National de la Santé et de la Recherche Médicale CIC 202, 2 boulevard Tonnellé, F-37044 Tours Cedex 9, Tours, France.

\section{Authors' contributions}

DM drafted the manuscript. FL and ED participated in patient clinical assessment and performed the statistical analysis. DW participated in patient clinical assessment and helped draft the manuscript. PG supervised the study design and helped draft the manuscript. DT performed the statistical analysis and pharmacokinetics modelling and helped draft the manuscript. GP participated in the study design and helped draft the manuscript. All authors read and approved the final manuscript.

\section{Competing interests}

DM has a consultancy with Schering-Plough. Payment for lectures was received from Union Chimique Belge, Merck Sharpe \& Dohme, Roche and Amgen. Travel, accommodations and meeting expenses were paid by Roche, Bristol-Myers Squibb, Servier and Abbott Laboratories. FL received compensation for travel, accommodations and meeting expenses from Abbott Laboratories and Servier. DW is a board member for Pfizer; has grants or grants pending from Abbott Laboratories, BMS, Schering-Plough, Wyeth, Roche-Chugai and Servier; has received payment for lectures from Abbott Laboratories, BMS Schering-Plough, Pfizer and Roche Chugai; and has received compensation for travel, accommodations and meeting expenses from Abbott Laboratories, BMS and Amgen. DT has no competing interests to declare. ED has a consultancy at Abbott Laboratories and received compensation for travel, accommodations and meeting expenses from UCB, Servier and Roche. GP is a board member for Roche and holds a consultancy with LFB (Laboratoire Français du fractionnement et des biotechnologies), received payment for the development of educational presentations from Janssen-Cilag and received compensation for travel, accommodations and meeting expenses from Roche. PG is a board member of and has consultancies with Abbott Laboratories, BMS and Pfizer; received payment for lectures from Abbott Laboratories, BMS, MSD, Pfizer, Roche and Schering-Plough; and was compensated for travel, accommodations and meeting expenses by Abbott Laboratories, MSD, Pfizer, Roche and ScheringPlough.

\section{Received: 11 February 2011 Revised: 21 March 2011}

Accepted: 3 June 2011 Published: 3 June 2011

\section{References}

1. van der Heijde D, Dijkmans B, Geusens P, Sieper J, DeWoody K, Williamson $P$, Braun J: Efficacy and safety of infliximab in patients with ankylosing spondylitis: results of a randomized, placebo-controlled trial (ASSERT). Arthritis Rheum 2005, 52:582-591.

2. Haibel H, Brandt HC, Song $\mathrm{H}$, Brandt A, Listing J, Rudwaleit M, Sieper J: No efficacy of subcutaneous methotrexate in active ankylosing spondylitis: a 16-week open-label trial. Ann Rheum Dis 2007, 66:419-421.

3. Altan L, Bingol U, Karakoc Y, Aydiner S, Yurtkuran M, Yurtkuran M: Clinical investigation of methotrexate in the treatment of ankylosing spondylitis. Scand J Rheumatol 2001, 30:255-259.

4. Gonzalez-Lopez L, Garcia-Gonzalez A, Vazquez-Del-Mercado M, MuñozValle JF, Gamez-Nava Jl: Efficacy of methotrexate in ankylosing spondylitis: a randomized, double blind, placebo controlled trial. J Rheumatol 2004, 31:1568-1574.

5. Roychowdhury B, Bintley-Bagot S, Bulgen DY, Thompson RN, Tunn EJ, Moots RJ: Is methotrexate effective in ankylosing spondylitis? Rheumatology (Oxford) 2002, 41:1330-1332.

6. Chen J, Liu C, Lin J: Methotrexate for ankylosing spondylitis. Cochrane Database Syst Rev 2006, 4:CD004524.

7. Pérez-Guijo VC, Cravo AR, Castro Mdel C, Font P, Muñoz-Gomariz E, Collantes-Estevez $\mathrm{E}$ : Increased efficacy of infliximab associated with methotrexate in ankylosing spondylitis. Joint Bone Spine 2007, 74:254-258.

8. Breban M, Ravaud P, Claudepierre P, Baron G, Henry YD, Hudry C, EullerZiegler L, Pham T, Solau-Gervais E, Chary-Valckenaere I, Marcelli C, Perdriger $A$, Le Loët $X$, Wendling $D$, Fautrel $B$, Fournié $B$, Combe $B$, Gaudin P, Jousse S, Mariette X, Baleydier A, Trape G, Dougados M, French Ankylosing Spondylitis Infliximab Network: Maintenance of infliximab 
treatment in ankylosing spondylitis: results of a one-year randomized controlled trial comparing systematic versus on-demand treatment. Arthritis Rheum 2008, 58:88-97.

9. Pham T, Fautrel B, Dernis E, Goupille P, Guillemin F, Le Loët X, Ravaud P, Claudepierre P, Miceli-Richard C, de Bandt M, Breban M, Maillefert JF, Masson C, Saraux A, Schaeverbeke T, Wendling D, Mariette X, Combe B, Club Rhumatismes et Inflammation (CRI/SFR): Recommendations of the French Society for Rheumatology regarding TNFa antagonist therapy in patients with ankylosing spondylitis or psoriatic arthritis: 2007 update. Joint Bone Spine 2007, 74:638-646.

10. van der Linden S, Valkenburg HA, Cats A: Evaluation of diagnostic criteria for ankylosing spondylitis: a proposal for modification of the New York criteria. Arthritis Rheum 1984, 27:361-368.

11. Braun J, Pham T, Sieper J, Davis J, van der Linden S, Dougados M, van der Heijde D: International ASAS consensus statement for the use of antitumour necrosis factor agents in patients with ankylosing spondylitis. Ann Rheum Dis 2003, 62:817-824.

12. Ternant D, Mulleman D, Degenne D, Willot S, Guillaumin JM, Watier $H$ Goupille P, Paintaud G: An enzyme-linked immunosorbent assay for therapeutic drug monitoring of infliximab. Ther Drug Monit 2006, 28:169-174.

13. The R Project for Statistical Computing. [http://www.R-project.org/].

14. Krzysiek R, Breban M, Ravaud P, Prejean MV, Wijdenes J, Roy C, Henry YD, Barbey C, Trappe G, Dougados M, Emilie D, French Ankylosing Spondylitis Infliximab Network: Circulating concentration of infliximab and response to treatment in ankylosing spondylitis: results from a randomized control study. Arthritis Rheum 2009, 61:569-576.

15. Visser K, Katchamart W, Loza E, Martinez-Lopez JA, Salliot C, Trudeau J, Bombardier C, Carmona L, van der Heijde D, Bij|sma JW, Boumpas DT, Canhao H, Edwards CJ, Hamuryudan V, Kvien TK, Leeb BF, Martín-Mola EM, Mielants H, Müller-Ladner U, Murphy G, Østergaard M, Pereira IA, RamosRemus C, Valentini G, Zochling J, Dougados M: Multinational evidencebased recommendations for the use of methotrexate in rheumatic disorders with a focus on rheumatoid arthritis: integrating systematic literature research and expert opinion of a broad international panel of rheumatologists in the 3E Initiative. Ann Rheum Dis 2009, 68:1086-1093.

16. de Vries MK, Wolbink GJ, Stapel SO, de Vrieze H, van Denderen JC, Dijkmans BA, Aarden LA, van der Horst-Bruinsma IE: Decreased clinical response to infliximab in ankylosing spondylitis is correlated with antiinfliximab formation. Ann Rheum Dis 2007, 66:1252-1254.

17. Maini RN, Breedveld FC, Kalden JR, Smolen JS, Davis D, Macfarlane JD, Antoni C, Leeb B, Elliott MJ, Woody JN, Schaible TF, Feldmann M: Therapeutic efficacy of multiple intravenous infusions of anti-tumor necrosis factor a monoclonal antibody combined with low-dose weekly methotrexate in rheumatoid arthritis. Arthritis Rheum 1998, 41:1552-1563.

18. Hanauer SB, Feagan BG, Lichtenstein GR, Mayer LF, Schreiber $S$, Colombel JF, Rachmilewitz D, Wolf DC, Olson A, Bao W, Rutgeerts P. Maintenance infliximab for Crohn's disease: the ACCENT I randomised trial. Lancet 2002, 359:1541-1549.

19. Baert F, Noman M, Vermeire S, Van Assche G, D' Haens G, Carbonez A Rutgeerts $P$ : Influence of immunogenicity on the long-term efficacy of infliximab in Crohn's disease. N Engl J Med 2003, 348:601-608.

20. Bendtzen K, Geborek P, Svenson M, Larsson L, Kapetanovic MC, Saxne T: Individualized monitoring of drug bioavailability and immunogenicity in rheumatoid arthritis patients treated with the tumor necrosis factor alpha inhibitor infliximab. Arthritis Rheum 2006, 54:3782-3789.

21. Wolbink GJ, Voskuyl AE, Lems WF, de Groot E, Nurmohamed MT, Tak PP, Dijkmans BA, Aarden L: Relationship between serum trough infliximab levels, pretreatment $C$ reactive protein levels, and clinical response to infliximab treatment in patients with rheumatoid arthritis. Ann Rheum Dis 2005, 64:704-707.

doi:10.1186/ar3350

Cite this article as: Mulleman et al:: Infliximab in ankylosing spondylitis: alone or in combination with methotrexate? A pharmacokinetic comparative study. Arthritis Research \& Therapy 2011 13:R82.

\section{Submit your next manuscript to BioMed Central and take full advantage of:}

- Convenient online submission

- Thorough peer review

- No space constraints or color figure charges

- Immediate publication on acceptance

- Inclusion in PubMed, CAS, Scopus and Google Scholar

- Research which is freely available for redistribution

Submit your manuscript at www.biomedcentral.com/submit 